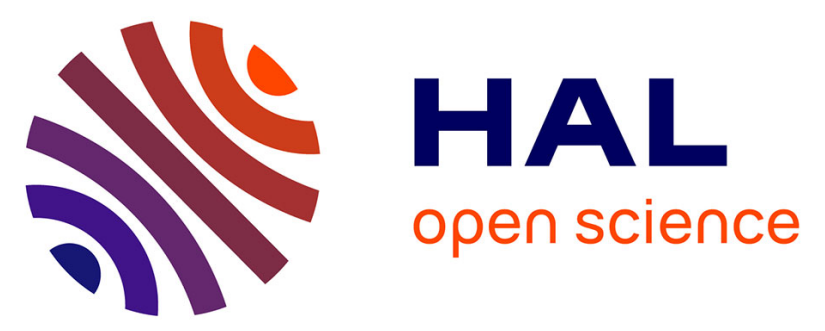

\title{
Sinunanolobatone A, an Anti-inflammatory Diterpenoid with Bicyclo[13.1.0]pentadecane Carbon Scaffold, and Related Casbanes from the Sanya Soft Coral Sinularia nanolobata
}

Zi-Rong Zeng, Wang-Sheng Li, Bastien Nay, Pei Hu, Hai-Yan Zhang, Hong Wang, Xu-Wen Li, Yue-Wei Guo

\section{To cite this version:}

Zi-Rong Zeng, Wang-Sheng Li, Bastien Nay, Pei Hu, Hai-Yan Zhang, et al.. Sinunanolobatone A, an Anti-inflammatory Diterpenoid with Bicyclo[13.1.0]pentadecane Carbon Scaffold, and Related Casbanes from the Sanya Soft Coral Sinularia nanolobata. Organic Letters, 2021, 23 (19), pp.7575-7579. 10.1021/acs.orglett.1c02772 . hal-03368762

\section{HAL Id: hal-03368762 https://hal.science/hal-03368762}

Submitted on 7 Oct 2021

HAL is a multi-disciplinary open access archive for the deposit and dissemination of scientific research documents, whether they are published or not. The documents may come from teaching and research institutions in France or abroad, or from public or private research centers.
L'archive ouverte pluridisciplinaire HAL, est destinée au dépôt et à la diffusion de documents scientifiques de niveau recherche, publiés ou non, émanant des établissements d'enseignement et de recherche français ou étrangers, des laboratoires publics ou privés. 


\title{
Sinunanolobatone A, an Anti-inflammatory Diterpenoid with Bicy- clo[13.1.0]pentadecane Carbon Scaffold, and Related Casbanes from the Sanya Soft Coral Sinularia nanolobata
}

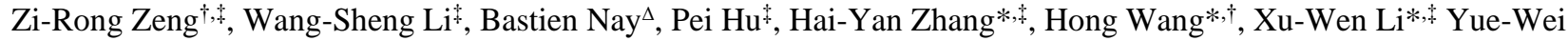 \\ $\mathrm{GuO}^{*, \dagger,+, \S}$
}

${ }^{\dagger}$ Collaborative Innovation Center of Yangtze River Delta Region Green Pharmaceuticals and College of Pharmaceuticals and College of Pharmaceutical Science, Zhejiang University of Technology, Hangzhou 310014, China

* State Key Laboratory of Drug Research, Shanghai Institute of Materia Medica, Chinese Academy of Sciences, 555 Zu Chong Zhi Road, Zhangjiang Hi-Tech Park, Shanghai 201203, China

${ }^{\Delta}$ Laboratoire de Synthèse Organique, Ecole Polytechnique, ENSTA, CNRS, Institut Polytechnique de Paris, 91128 Palaiseau Cedex, France

$\S$ Bohai rim Advanced Research Institute for Drug Discovery, 198 Binhai East Road, High-tech Zone, Yantai, Shandong Province 264000, China

Supporting Information

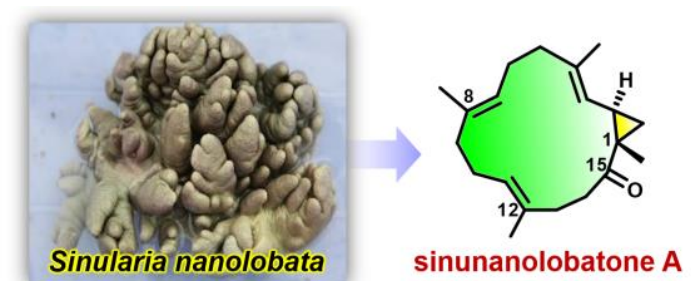

\begin{abstract}
A novel diterpenoid, sinunanolobatone A (1), featuring an unprecedented bicyclo[13.1.0]pentadecane carbon framework, along with two new casbane diterpenoids ( 2 and 3), and five known related ones (4-8) were isolated from the Sanya soft coral Sinularia nanolobata. The structures of the new compounds were established by detailed spectroscopic analysis, X-ray diffraction analysis, chemical reactions, or quantum chemical computation method. A plausible biosynthetic pathway of $\mathbf{1}$ and its biogenetic relationship with co-occurring casbanes was proposed. In bioassay, the novel compound 1 showed significant inhibitory activity against lipopolysaccharide (LPS) induced inflammation in BV-2 microglial cells.
\end{abstract}

Soft corals of the genus Sinularia (order Alcyonacea, family Alcyoniidae) are rich sources of diverse secondary metabolites, especially various types of terpenoids, with widespread biological activities, which allowed them becoming an attractive research target over marine natural product chemistry community. ${ }^{1}$ Among all the species of Sinularia, S. nanolobata have been reported to comprise a large number of terpenoids, including diterpenoids (cubitanes, cembranoids, amphilectanes), norditerpenoids (tetranorditerpenoids, norcembranoids, nanolobatanes), sesquiterpenoids (cadinanes, valerenanes), and norsesquiterpenoids. ${ }^{1,2}$ However, casbane-type diterpenoids have never been reported before from this animal. In fact, the casbane diterpenoids are relatively unusual in nature, and they were biosynthetically derived from the more common cembranoids and characterized by the presence of a dimethyl-cyclopropyl moiety fused to a 14-membered macrocycle. Casbanes were reported to possess various biological properties, such as anti-inflammatory, anti-cancer and anti-bacterial activities, ${ }^{3}$ indicating their potential on new drug discovery.

South China Sea invertebrates were rich sources of structurally novel and biologically active natural products by many recent chemical and biological investigations. ${ }^{4}$ In order to find more novel and bioactive metabolites from this sea area, the title animals collected off the coast of Ximao Island, Sanya, Hainan Province, China, were chemically investigated for the first time, resulting in the discovery of one novel diterpenoid, sinunanolobatone A (1), with an unprecedented bicyclo[13.1.0]pentadecane carbon skeleton, and two new related casbane-type diterpenoids ( 2 and $\mathbf{3}$ ) (Figure 1). Herein, the isolation, structural elucidation, bioactivity evaluation, and plausible biosynthetic pathway of the new isolates are reported.
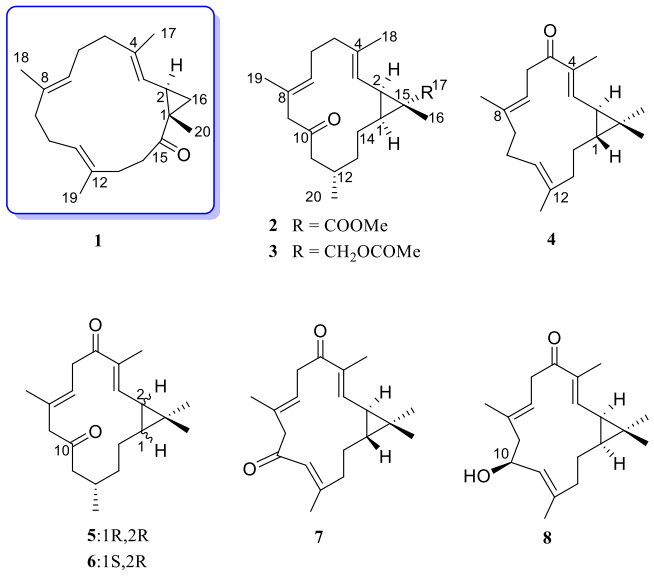

Figure 1. Structures of compounds $\mathbf{1}-\mathbf{8}$.

Samples of $S$. nanolobata were extracted as previously 
described, ${ }^{4}$ affording the pure compounds $\mathbf{1}$ (1.0mg), 2 (11.3mg), 3 (6.3mg), 4 (2.6mg), 5 (5.0mg), 6 (18.5mg), 7 $(2.6 \mathrm{mg})$, and $8(3.0 \mathrm{mg})$, respectively. By direct comparison of spectroscopic data and specific optical rotation with those reported in the literature, compounds 4-8 were identified as known casbane diterpenoids. ${ }^{4,5}$

Sinunanolobatone A (1) was obtained as a colorless solid. Its molecular formula was determined to be $\mathrm{C}_{20} \mathrm{H}_{30} \mathrm{O}$ from the HREIMS ion peak at $m / z 286.2282$ ([M] $]^{+}$, calcd 286.2291), indicating six double bond equivalents (DBEs). The ${ }^{13} \mathrm{C} N M R$, DEPT, and HSQC spectra of 1 revealed the presence of 20 carbon signals, including four methyls, seven $\mathrm{sp}^{3}$ methylenes, one $\mathrm{sp}^{3}$ methine and three $\mathrm{sp}^{2}$ methines as well as one ketone carbonyl $\left(\delta_{\mathrm{C}} 213.6\right)$. The diagnostic ${ }^{1} \mathrm{H}$ and ${ }^{13} \mathrm{C}$ NMR resonances, as well as the coupling constants of the connected protons (Table 1), suggested the presence of three trisubstituted double bonds $\left[\delta_{\mathrm{H}} 4.90(1 \mathrm{H}, \mathrm{d}, J=8.2 \mathrm{~Hz}) / \delta_{\mathrm{C}} 123.1(\mathrm{CH}), \delta_{\mathrm{C}} 138.8(\mathrm{qC})\right.$; $\delta_{\mathrm{H}} 4.97(1 \mathrm{H}, \mathrm{dd}, J=9.5,3.6 \mathrm{~Hz}) / \delta_{\mathrm{C}} 125.4(\mathrm{CH}), \delta_{\mathrm{C}} 134.4(\mathrm{qC}) ; \delta_{\mathrm{H}}$ $5.14(1 \mathrm{H}$, ddt, $\left.J=5.3,2.7,1.3 \mathrm{~Hz}) / \delta_{\mathrm{C}} 125.3(\mathrm{CH}), \delta_{\mathrm{C}} 133.7(\mathrm{qC})\right]$. The above functionalities accounted for four of the six DBEs, suggesting the presence of a bicyclic ring system in $\mathbf{1}$.

Table 1. ${ }^{1} \mathrm{H}$ NMR $\left(\delta_{\mathrm{H}}\right)$ and ${ }^{13} \mathrm{C}$ NMR $\left(\delta_{\mathrm{C}}\right)$ Data for $\mathbf{1}$ in $\mathrm{CDCl}_{3}$.

\begin{tabular}{|c|c|c|}
\hline \multirow[t]{2}{*}{ No. } & \multicolumn{2}{|c|}{1} \\
\hline & $\delta_{\mathrm{H}}$, mult $(J \mathrm{~Hz})^{a}$ & $\delta_{\mathrm{C}}{ }^{b}$ \\
\hline 1 & & $30.8 \mathrm{qC}$ \\
\hline 2 & $1.75 \mathrm{~m}$ & $31.3 \mathrm{CH}$ \\
\hline 3 & $4.90 \mathrm{~d}(8.2)$ & $123.1 \mathrm{CH}$ \\
\hline 4 & & $138.8 \mathrm{qC}$ \\
\hline $5 \mathrm{a}$ & $2.24 \mathrm{~m}$ & $38.9 \mathrm{CH}_{2}$ \\
\hline $5 b$ & $2.11 \mathrm{~m}$ & \\
\hline $6 \mathrm{a}$ & $2.36 \mathrm{~m}$ & $25.1 \mathrm{CH}_{2}$ \\
\hline $6 \mathrm{~b}$ & $2.06 \mathrm{~m}$ & \\
\hline 7 & $4.97 \mathrm{dd}(9.5,3.6)$ & $125.4 \mathrm{CH}$ \\
\hline 8 & & $134.4 \mathrm{qC}$ \\
\hline $9 \mathrm{a}$ & $2.16 \mathrm{~m}$ & $38.9 \mathrm{CH}_{2}$ \\
\hline $9 \mathrm{~b}$ & $1.93 \mathrm{~m}$ & \\
\hline $10 \mathrm{a}$ & $2.16 \mathrm{~m}$ & $23.9 \mathrm{CH}_{2}$ \\
\hline $10 \mathrm{~b}$ & $2.01 \mathrm{~m}$ & \\
\hline 11 & $5.14 \mathrm{ddt}(5.3,2.7,1.3)$ & $125.3 \mathrm{CH}$ \\
\hline 12 & & $133.7 \mathrm{qC}$ \\
\hline $13 \mathrm{a}$ & $2.45 \mathrm{~m}$ & $36.5 \mathrm{CH}_{2}$ \\
\hline $13 b$ & $2.17 \mathrm{~m}$ & \\
\hline $14 \mathrm{a}$ & $2.85 \mathrm{ddd}(12.0,5.3,4.6)$ & $38.0 \mathrm{CH}_{2}$ \\
\hline $14 b$ & $2.34 \operatorname{td}(12.0,4.6)$ & \\
\hline 15 & & $213.6 \mathrm{qC}$ \\
\hline $16 \mathrm{a}$ & $1.83 \mathrm{dd}(9.2,3.7)$ & $22.9 \mathrm{CH}_{2}$ \\
\hline $16 \mathrm{~b}$ & $0.50 \mathrm{dd}(6.5,3.7)$ & \\
\hline 17 & $1.63 \mathrm{~s}$ & $15.8 \mathrm{CH}_{3}$ \\
\hline 18 & $1.54 \mathrm{~s}$ & $15.5 \mathrm{CH}_{3}$ \\
\hline 19 & $1.59 \mathrm{~s}$ & $15.6 \mathrm{CH}_{3}$ \\
\hline 20 & $1.39 \mathrm{~s}$ & $16.7 \mathrm{CH}_{3}$ \\
\hline
\end{tabular}

${ }^{a}$ Recorded at $600 \mathrm{MHz} .{ }^{b}$ Recorded at $125 \mathrm{MHz}$. Assignments were deduced by analysis of 1D and 2D NMR spectra.

The planar structure of $\mathbf{1}$ was further determined by the ${ }^{1} \mathrm{H}$ ${ }^{1} \mathrm{H}$ COSY and HMBC experiments (Figures S6 and S7). Analysis of the COSY spectrum of $\mathbf{1}$ discovered the proton connectivity for four structure fragments $\mathbf{a}-\mathbf{d}$ (Figure 2) by clear correlations of $\mathrm{H}-3\left(\delta_{\mathrm{H}} 4.90\right) / \mathrm{H}-2\left(\delta_{\mathrm{H}} 1.75\right) / \mathrm{H}_{2}-16\left(\delta_{\mathrm{H}} 0.50,1.83\right)$ (a); $\mathrm{H}_{2}-5\left(\delta_{\mathrm{H}} 2.11,2.24\right) / \mathrm{H}_{2}-6\left(\delta_{\mathrm{H}} 2.06,2.36\right) / \mathrm{H}-7\left(\delta_{\mathrm{H}} 4.97\right)(\mathbf{b})$; $\mathrm{H}_{2}-9\left(\delta_{\mathrm{H}} 1.93,2.16\right) / \mathrm{H}_{2}-10\left(\delta_{\mathrm{H}} 2.01,2.16\right) / \mathrm{H}-11\left(\delta_{\mathrm{H}} 5.14\right)(\mathbf{c}) ;$ $\mathrm{H}_{2}-13\left(\delta_{\mathrm{H}} 2.17,2.45\right) / \mathrm{H}_{2}-14\left(\delta_{\mathrm{H}} 2.34,2.85\right)(\mathbf{d})$, respectively. Further, the presence of a cyclopropane ring A was rapidly identified by the connection of fragment $\mathbf{a}$ with $\mathrm{C}-1$, with the clear HMBC correlations from $\mathrm{H}_{3}-20$ to $\mathrm{C}-1 / \mathrm{C}-15 / \mathrm{C}-16$, from
H-2 to C-15, and from H-16 to C-15. The subunits b-d were connected with the cyclopropane ring $\mathrm{A}$, bearing in mind three methyls at $\delta_{\mathrm{C}} 15.8,15.5$ and 15.6, three trisubstituted double bonds, and one ketone carbonyl at $\delta_{\mathrm{C}} 213.6$, by detailed interpretation of the well resolved $\mathrm{HMBC}$ correlations from $\mathrm{H}_{3}-17$ to $\mathrm{C}-3 / \mathrm{C}-4 / \mathrm{C}-5$, from $\mathrm{H}-3$ to $\mathrm{C}-2 / \mathrm{C}-5 / \mathrm{C}-16 / \mathrm{C}-17$, from $\mathrm{H}_{3}-18$ to C-7/C-8/C-9, from $\mathrm{H}-7$ to C-5/C-6/C-9/C-18, from $\mathrm{H}_{3}-19$ to C$11 / \mathrm{C}-12 / \mathrm{C}-13$, from $\mathrm{H}-11$ to $\mathrm{C}-9 / \mathrm{C}-10 / \mathrm{C}-13 / \mathrm{C}-19$, and from $\mathrm{H}_{2}-13$ to $\mathrm{C}-12 / \mathrm{C}-14 / \mathrm{C}-15 / \mathrm{C}-19$, leading to the construction of an uncommon bicyclo[13.1.0]pentadecane carbon framework towards the planar structure of $\mathbf{1}$.

The relative configuration of $\mathbf{1}$ was established by analysis of its NOESY spectrum (Figure 2). Initially, the NOE interaction between $\mathrm{H}-3\left(\delta_{\mathrm{H}} 4.90\right)$ and $\mathrm{H}-5 \mathrm{~b}\left(\delta_{\mathrm{H}} 2.11\right)$, between $\mathrm{H}-7\left(\delta_{\mathrm{H}}\right.$ $4.97)$ and $\mathrm{H}-9 \mathrm{~b}\left(\delta_{\mathrm{H}} 1.93\right), \mathrm{CH}_{3}-18\left(\delta_{\mathrm{H}} 1.54\right)$ and $\mathrm{H}-6 \mathrm{a}\left(\delta_{\mathrm{H}} 2.36\right)$, $\mathrm{H}-11\left(\delta_{\mathrm{H}} 5.14\right)$ and $\mathrm{H}-13 \mathrm{~b}\left(\delta_{\mathrm{H}} 2.17\right)$, as well as between $\mathrm{CH}_{3}-19$ $\left(\delta_{\mathrm{H}} 1.59\right)$ and $\mathrm{H}-10 \mathrm{a}\left(\delta_{\mathrm{H}} 2.16\right)$ assigned the $E$-geometry of $\Delta^{3,4}$, $\Delta^{7,8}$, and $\Delta^{11,12}$, respectively, which was supported by the far below 20 ppm of ${ }^{13} \mathrm{C}$ chemical shifts of $\mathrm{CH}_{3}-17 / 18 / 19 .{ }^{5,6}$ Further, the obvious correlation between $\mathrm{H}_{3}-20\left(\delta_{\mathrm{H}} 1.39\right)$ and $\mathrm{H}-16 \mathrm{~b}\left(\delta_{\mathrm{H}}\right.$ $0.50)$ revealed that the $\mathrm{CH}_{3}-20$ and $\mathrm{H}-16 \mathrm{~b}$ were of the same orientation, arbitrarily assigned as $\beta$ configuration. The NOE correlation between $\mathrm{H}-2\left(\delta_{\mathrm{H}} 1.75\right)$ and $\mathrm{H}-16 \mathrm{a}\left(\delta_{\mathrm{H}} 1.83\right)$ disclosed the $\alpha$ orientation of $\mathrm{H}-2$. Finally, the relative configuration of two stereogenic centers of 1 was established as $1 S^{*}, 2 R^{*}$.

TDDFT-ECD (time-dependent density functional theoryelectronic circular dichroism calculation) has been verified to be a dependable method for the identification of the absolute stereochemistry of natural products. ${ }^{4}$ Therefore, it has been applied for the determination of the absolute configuration of $\mathbf{1}$. As shown in Figure 3, the Boltzmann-averaged ECD spectrum of $(1 S, 2 R)$-1 displayed a similar curve compared to the experimental one, while the opposite to its enantiomer, which was suggestive of the $(1 S, 2 R)$ absolute configuration for $\mathbf{1}$.

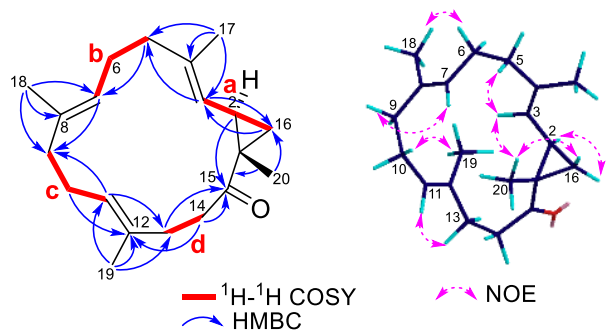

Figure 2. ${ }^{1} \mathrm{H}-{ }^{1} \mathrm{H}$ COSY, key HMBC, and NOE correlations of compound $\mathbf{1}$.

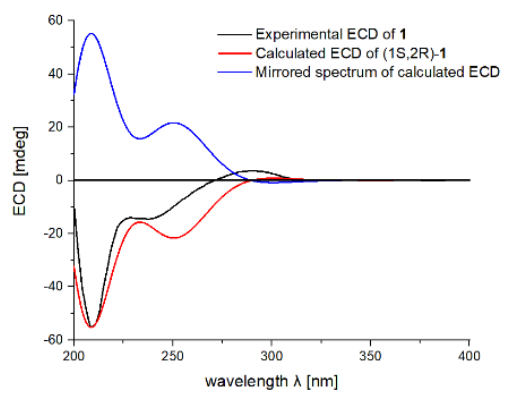

Figure 3. Experimental ECD spectrum of sinunanolobatone A (1) (black, $1 S, 2 R)$, calculated spectrum of $\mathbf{1}(\mathrm{red}, 1 S, 2 R)$ and its enantiomer (blue, $1 R, 2 S$ ).

Compound 2 was obtained as a colorless crystal. Its molecular formula, $\mathrm{C}_{21} \mathrm{H}_{32} \mathrm{O}_{3}$, was determined by the HR-ESIMS ion peak at $m / z 333.2428\left([\mathrm{M}+\mathrm{H}]^{+}\right.$, calcd for 333.2424), indicating 
six DBEs. The ${ }^{13} \mathrm{C}$ NMR, DEPT, and HSQC spectra (Table S2, Figures $\mathrm{S} 12$ and $\mathrm{S} 13$ ) of $\mathbf{2}$ revealed 21 carbon signals, including four methyls, one methoxy group, six $\mathrm{sp}^{3}$ methylenes, three $\mathrm{sp}^{3}$ methines and two $\mathrm{sp}^{2}$ methines, as well as one ketone $\left(\delta_{\mathrm{C}} 209.8\right)$ and one ester carbonyl $\left(\delta_{\mathrm{C}} 176.8\right)$.

Analysis of the ${ }^{1} \mathrm{H}-{ }^{1} \mathrm{H}$ COSY spectrum of 2 rapidly discovered two structure fragments by clear correlations of $\mathrm{H}-2\left(\delta_{\mathrm{H}}\right.$ $2.16) / \mathrm{H}-1 \quad\left(\delta_{\mathrm{H}} 1.50\right) / \mathrm{H}_{2}-14\left(\delta_{\mathrm{H}} 0.81,1.56\right) / \mathrm{H}_{2}-13\left(\delta_{\mathrm{H}} 1.15\right.$, $1.31) / \mathrm{H}-12\left(\delta_{\mathrm{H}} 1.99\right) / \mathrm{H}_{2}-11\left(\delta_{\mathrm{H}} 2.22,2.43\right)(\mathbf{a})$ and $\mathrm{H}_{2}-5\left(\delta_{\mathrm{H}} 2.16\right.$ $2.21) / \mathrm{H}_{2}-6\left(\delta_{\mathrm{H}} 2.19,2.27\right) / \mathrm{H}-7\left(\delta_{\mathrm{H}} 5.11\right)(\mathbf{b})$. The connection of the two structure moieties with other quaternary carbons were further determined by the analysis of HMBC spectrum (Figure $4)$. The HMBC cross peaks from $\mathrm{H}_{3}-18\left(\delta_{\mathrm{H}} 1.67\right)$ to $\mathrm{C}-3 / \mathrm{C}-4 / \mathrm{C}-$ 5 , from $\mathrm{H}_{3}-19\left(\delta_{\mathrm{H}} 1.70\right)$ to $\mathrm{C}-7 / \mathrm{C}-8 / \mathrm{C}-9$, from $\mathrm{H}_{3}-20\left(\delta_{\mathrm{H}} 0.93\right)$ to $\mathrm{C}-11 / \mathrm{C}-12 / \mathrm{C}-13$, from $\mathrm{H}_{2}-11\left(\delta_{\mathrm{H}} 2.22,2.43\right)$ to $\mathrm{C}-10$, from $\mathrm{H}_{2}-9\left(\delta_{\mathrm{H}} 2.89,3.05\right)$ to $\mathrm{C}-10$ revealed a fourteen-membered ring B. Moreover, The HMBC correlations from $\mathrm{H}-1$ to $\mathrm{C}-3 / \mathrm{C}-13 / \mathrm{C}-$ $15 / \mathrm{C}-17$ and from $\mathrm{H}-2$ to $\mathrm{C}-1 / \mathrm{C}-4 / \mathrm{C}-14 / \mathrm{C}-15 / \mathrm{C}-17$, was easy to draw the conclusion that the other partial structure is a cyclopropane ring A, leading to the entire structure of compound $\mathbf{2}$, a casbane-type diterpenoid (Figure S2).

To further confirm the structure and absolute configuration of $\mathbf{2}$, we attempted and fortunately obtained suitable single crystals from the recrystallization of $\mathbf{2}$ in methanol, which allowed a successful performance of X-ray crystallography studying using $\mathrm{Cu} \mathrm{K} \alpha$ radiation $(\lambda=1.54178 \AA)$. Analysis of the $\mathrm{X}$-ray data unambiguously confirmed the planar structure of $\mathbf{2}$ and its absolute configuration as $1 S, 2 R, 12 S, 15 R$ [Flack parameter was 0.09(11)] (Figure 4, CCDC 2103366). Thus, the structure of 2 was determined as shown in Figure 1.

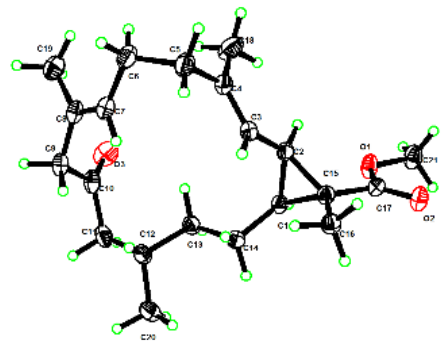

Figure 4. Perspective ORTEP drawing of X-ray structure of 2 (displacement ellipsoids are drawn at the $50 \%$ probability level).

Compound 3 was obtained as a colorless solid. Its molecular formular was established to be $\mathrm{C}_{22} \mathrm{H}_{34} \mathrm{O}_{3}$ by the HR-EIMS ion peak at $\mathrm{m} / \mathrm{z} 346.2503\left([\mathrm{M}]^{+}\right.$, calcd 346.2502), implying six DBEs. The NMR data of compound $\mathbf{3}$ was extremely reminiscent of those of $\mathbf{2}$, and the only difference occurred on the C-17 position. Detailed 1D and 2D NMR data comparison revealed that the $-\mathrm{COOMe}$ group $\left(\mathrm{Me}: \delta_{\mathrm{H}} 3.64, \delta_{\mathrm{C}} 52.1\right)$ at $\mathrm{C}-17$ position of 2 was replaced by the $-\mathrm{CH}_{2} \mathrm{OCOMe}$ group $\left(\mathrm{Me}: \delta_{\mathrm{H}}\right.$ $\left.2.05, \delta_{\mathrm{C}} 21.2\right)$, which is in accordance to one additional carbon in 3. Therefore, $\mathbf{3}$ was determined to be an analog of $\mathbf{2}$ by a different functional group at $\mathrm{C}-17$. The structure of $\mathbf{3}$, especially its stereochemsitry, was further confirmed by chemical reactions. Initially, the hydrolysis of $\mathbf{2}$ and $\mathbf{3}$ by KOH in THF$\mathrm{H}_{2} \mathrm{O}(3: 1)$ resulted in the acids $\mathbf{2} \mathbf{a} / \mathbf{2} \mathbf{b}$ and the alcohol $\mathbf{3 a} / \mathbf{3} \mathbf{b}$, respectively. Further, the oxidation of $\mathbf{3 a}$ in the presence of Dess-Martin periodinane (DMP) and $\mathrm{NaHCO}_{3}$ in $\mathrm{CH}_{2} \mathrm{Cl}_{2}$ led to the aldehyde $3 \mathbf{c}$, which then oxidated by Jone's reagent to afford the acid 3d. 3d was proved to be $2 \mathbf{a}$ by LC-MS-MS analysis, with cosine similarity score of 0.86 , and the same sign of their specific rotation $\left\{[\alpha]_{\mathrm{D}}^{20}-30.5(c 0.10, \mathrm{MeOH})\right.$ for $\mathbf{2 a}$ and $[\alpha]_{\mathrm{D}}^{20}-18.3(c 0.05, \mathrm{MeOH})$ for $\left.\mathbf{3 d}\right\}$. It is worth mentioning that during the hydrolysis process of $\mathbf{2}$ and $\mathbf{3}$, a double bond shift via

an enolate intermediate occurred towards the synthetic new isomers $\mathbf{2 b}$ and $\mathbf{3 b}$, respectively (Scheme 1).

Scheme 1. Chemical correlation of compounds 2 and 3.

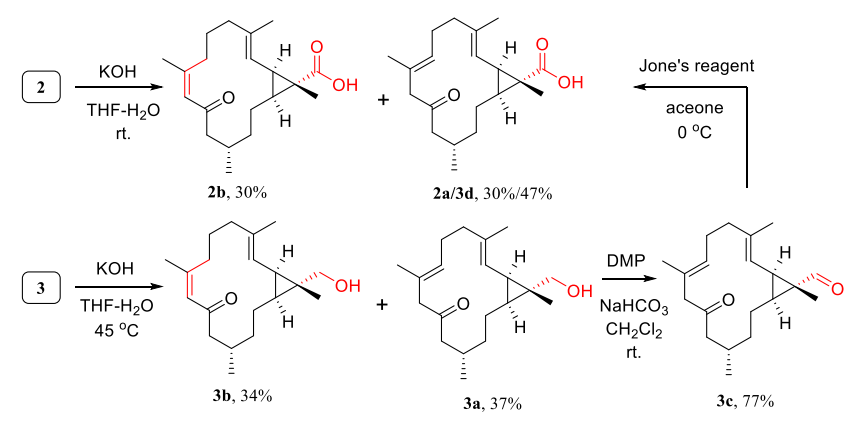

Although the structure of sinunanolobatone A (1) is obviously related to the co-occurring casbanes (2-8), its skeleton, characterized by a 15 -membered macrocycle fused to a cyclopropane ring, is unprecedented. It is interesting to note that the most significant difference between $\mathbf{1}$ and 2-8 is the ring size. To explain the formation of the framework of $\mathbf{1}$, a plausible biosynthetic pathway is proposed. As shown in Scheme 2, the common diterpene biosynthetic precursor $(E, E, E)$-geranylgeranyl diphosphate $[9,(E, E, E)$-GGPP $]$ undergo a 1,15 -cyclization will generate the key intermediate $\mathbf{1 0}$ with carbonium ion at $\mathrm{C}$ 14. ${ }^{7}$ Further, a 1,3-hydride shift of $\mathbf{1 0}$ (from H-1 to C-14) will afford the cationic intermediate $\mathbf{1 1}$, which followed by the cyclopropanation involving the formation of a new C-C bond from the $\mathrm{C}-16$ methyl to the $\mathrm{C}-1$ carbocation with loss of $\mathrm{H}-16$ to give the terpene $\mathbf{1 2}$. Then, oxidation at C-14 of $\mathbf{1 2}$ will yield sinunanolobatone A (1).

Scheme 2. Plausible biosynthetic pathway of the new compound 1 (OPP: diphosphate).
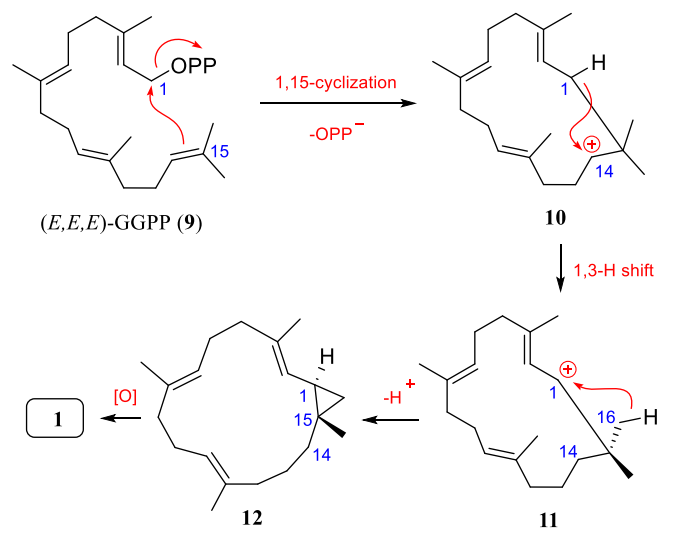

In the anti-inflammatory assay, compounds $\mathbf{1}, \mathbf{2 a}, \mathbf{3}, \mathbf{3 a}, \mathbf{4}, \mathbf{5}$, $\mathbf{7}$, and 8 at $20 \mu \mathrm{M}$ displayed inhibitory activity on NO production against LPS-induced inflammation-related BV-2 microglial cells (Table S3), comparable as that of the positive control resveratrol. In addition, these compounds at $20 \mu \mathrm{M}$ did not show noticeable cytotoxicity on BV-2 cells. Moreover, the novel compound $\mathbf{1}$ significantly reduced the mRNA levels of the pro-inflammatory cytokines IL- 6 and IL- $1 \beta$ mRNA in LPSstimulated BV-2 microglial cells at $10 \mu \mathrm{M}$ and $20 \mu \mathrm{M}$, respectively (Figure 5), which further demonstrated the anti-inflammatory effect of compound $\mathbf{1}$. 

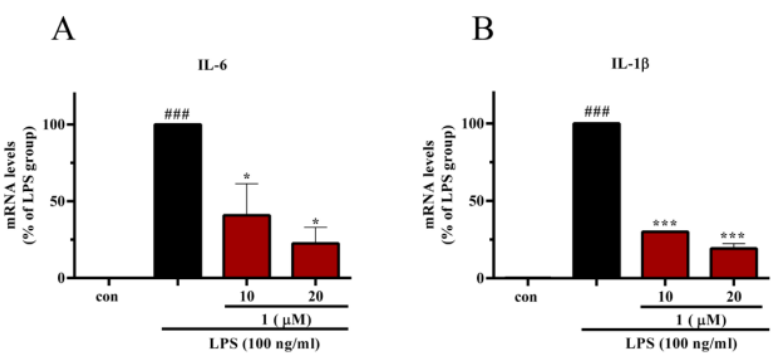

Figure 5. Compound 1 reduced the mRNA levels of IL-6 (A) and IL-1 $\beta$ (B) in LPS-stimulated BV-2 microglial cells. Data were normalized by the LPS group, and presented as Means \pm SEM $(n=3)$. \#\#\# $\mathrm{P}<0.001$ vs the control group, ${ }^{*} \mathrm{p}<0.05,{ }^{* * *} \mathrm{p}<0.001$ vs the LPS group.

In summary, this is the first chemical study of soft coral $S$. nanolobata from Ximao Island, Sanya. One novel diterpenoid, sinunanolobatone A (1), featuring an unprecedented bicyclo[13.1.0]pentadecane scaffold, two uncommom casbane diterpenoids ( 2 and $\mathbf{3}$ ), and five known casbane diterpenoids (4 8) were isolated and fully elucidated. The stereochemistry of the new compounds was determined by a series of reliable methods, including quantum mechanical calculations, X-ray diffraction analyses, and/or chemical correlations. The discovery of 1-3 has expanded the diversity and complexity of marine diterpenes. The biosynthetic proposal of the new compounds has given an insight for their biogenetic connection and further biomimetic synthesis, whereas the interesting anti-inflammatory activity of the novel compound $\mathbf{1}$ demonstrated its worthiness as a skeleton template for new inflammation related drug discovery

\section{- ASSOCIATED CONTENT}

\section{Supporting Information}

The Supporting Information is available free of charge on the ACS Publications website.

General information on the experiment, experimental procedures, characterization data, biological activity assays, and NMR spectra for all the new compounds (PDF).

\section{Accession Codes}

CCDC 2103366 contains the supplementary crystallographic data for this paper. These data can be obtained free of charge via www.ccdc.cam.ac.uk/data_request/cif, or by emailing data_request@ccdc.cam.ac.uk, or by contacting The Cambridge Crystallographic Data Centre, 12 Union Road, Cambridge CB2 1EZ, UK; fax: +44 1223336033.

\section{a AUTHOR INFORMATION}

\section{Corresponding Authors}

*E-mail: $\quad$ ywguo@simm.ac.cn; $\quad$ xwli@simm.ac.cn; hongw@zjut.edu.cn; hzhang@simm.ac.cn.

Notes

The authors declare no competing financial interest.

\section{- ACKNOWLEDGEMENTS}

This research work was financially supported by the National Natural Science Foundation of China (Nos. 81991521,
82022069, 42076099), the Shanghai Rising-Star Program (No. 20QA1411100), "Youth Innovation Promotion Association" of Chinese Academy of Sciences (No. Y202065), and the SKLDR/SIMM Project (No. SIMM2103ZZ-06). We thank Prof. Rui-Bo Wu from Zhongshan University for the nice discussion of the biosynthetic pathway, and Prof. Xiu-Bao Li from Hainan University for the taxonomic identification of the soft coral material.

\section{- REFERENCES}

(1) Hsu, F.-Y.; Wang, S.-K.; Duh, C.-Y. Mar. Drugs 2018, $16,40$.

(2) (a) Chao, C.-H.; Wu, C.-Y.; Huang, C.-Y.; Wang, H.-C.; Dai, C.-F.; Wu, Y.-C.; Sheu, J.-H. Mar. Drugs 2016, 14, 150. (b) Yamada, K.; Ujiie, T.; Yoshida, K.; Miyamotoo, T.; Higuchi, R. Tetrahedron 1997, 53, 4569-4578. (c) Tseng, Y.-J.; Wang, S.-K.; Duh, C.-Y. Mar. Drugs 2013, 11, 3288-3296. (d) Ngoc, N.T.; Huong, P.T.M. Nat. Prod. Res. 2017, 31, 1799-1804. (e) Ahmed, A.-F.; Su, J.-H.; Shiue, R.-T.; Pan, X.-J.; Dai, C.-F.; Kuo, Y.-H; Sheu, J.-H. J. Nat. Prod. 2004, 67, 592-597. (f) Tseng, Y.-J.; Wen, Z.-H.; Dai, C.-F.; Chiang, M.-Y.; Sheu, J.H. Org. Lett. 2009, 11, 5030-5032.

(3) Liu, J; Wu, M.-J.; Li H.; Wang, H.; Tang, W.; Gu, Y.-C.; Li, X.-W; Guo, Y.-W. Bioorg. Chem. 2021, 114, 105028.

(4) (a) Wu, Q.; Li, S.-W.; Xu, H.; Wang, H.; Hu, P.; Zhang, H.; Luo, C.; Chen, K.-X.; Nay, B.; Guo Y.-W.; Li, X.-W. Angew. Chem. Int. Ed. 2020, 59, 12105-12112. (b) Li, G.; Li, H.; Tang, W.; Guo, Y.-W.; Li, X.-W. Org. Lett. 2019, 21, 5660-5664. (c) Ye, F.; Li, J.; Wu, Y.; Zhu, Z.-D.; Mollo, E.; Gavagnin, M.; Gu, Y.-C.; Zhu, W.-L.; Li, X.-W.; Guo, Y.-W. Org. Lett. 2018, 20, 2637-2640. (d) Ye, F.; Zhu, Z.-D.; Chen, J.-S.; Li, J.; Gu, Y.-C.; Zhu, W.-L.; Li, X.-W.; Guo, Y.-W. Org. Lett. 2017, 19, 4183-4186. (e) Sun, L.-L.; Li, W.-S.; Li, J.; Zhang, H.-Y.; Yao, L.-G.; Luo, H.; Guo, Y.-W.; Li, X.-W. J. Org. Chem. 2021, 86, 3367-3376. (f) Li, Y.-F.; Li, S.-W.; Cuadrado, C.; Gao, C.-L.; Wu, Q.; Li, X.-L.; Pang, T.; Daranas, A. H.; Guo, Y.-W.; Li, X.-W. Chinese Chem. Lett. 2021, 32, 271-276. (g) Chen Z.-H., Li W.-S.; Zhang Z.-Y.; Luo H., Wang J.-R., Zhang H.-Y.; Zeng Z.-R.; Chen B.; Li X.-W.; Guo Y.-W. Org. Lett. 2021, 23, 5621-5625. (h) Li, T.; Tang, X.-L.; Luo, X.-C.; Wang, Q.; Liu, K.-C.; Zhang, Y.; de Voogd, N. J.; Yang, J.-J.; Li, P.-L.; Li, G.-Q. Org. Lett. 2021, 21, 9483-9486. (i) Gui, Y.-H; Jiao, W.-H.; Zhou, M.; Zhang, Y.; Zeng, D.-Q; Zhu, H.-R.; Liu, K.-C.; Sun, F.; Chen, H.-F.; Lin, H.-W. Org. Lett. 2019, 21, 767-770.

(5) Li, Y.; Carbone, M.; Vitale, R.M.; Amodeo, P.; Castelluccio, F.; Sicilia, G.; Mollo, E.; Nappo, M.; Cimino, G.; Guo, Y.-W.; Gavagnin, M. J. Nat. Prod. 2010, 73, 133-138.

(6) Bretmaier, E.; Voelter, W. Carbon-13 NMR Spectroscopy; VCH: New York, 1987, 192-196.

(7) (a) Robinson D. R.; West C. A. Biochemistry. 1970, 9, 80-89. (b) Zhan, C.-S.; Lei, L.; Liu, Z.-X.; Zhou, S.; Yang, C.K.; Zhu, X.-T.; Guo, H.; Zhang, F.; Peng, M.; Zhang, M.; Li, Y.-F.; Yang, Z.-X.; Sun, Y.-Y.; Shi, Y.-H.; Li, K.; Liu, L.; Shen, S.-Q.; Wang, X.-Y.; Shao, J.-W.; Jing, X.-Y.; Wang, Z.-X.; Li, Y.; Czechowski, T.; Hasegawa, M.; Graham, I.; Tohge, T.; Qu, L.-H.; Liu, X.-Q.; Fernie, A. R.; Chen, L.-L.; Yuan, M.; Luo, J. Nat. Plants 2020, 6, 1447-1454. 